\title{
Negotiative Hermeneutics of Khaled Abou El Fadl: Truth Postponement and Negotiating the Meaning of Text in Speaking In God's Name
}

\author{
Irza A. Syaddad
}

Universitas Islam Negeri Sunan Kalijaga Yogyakarta, Indonesia e-mail: syaddad.irza@gmail.com

\begin{tabular}{c} 
Article \\
Information \\
\hline
\end{tabular}

Submitted: July 06, 2020

Revised 1: July 07, 2020

Revised 2: October 31, 2020

Accepted: December 18, 2020

\section{Keywords}

Negotiative Hermeneutics, Khaled Abou El Fadl, Ontology, Epistemology
Abstract

This study aims to map the ontological and epistemological aspects of Negotiative Hermeneutics through a philosophical approach. Negotiative Hermeneutics is a new hermeneutic model initiated by Khaled Abou El Fadl to criticize gender-biased and misogyny fatwas issued by Al-Lajnah ad-Dā'imah li al-Buhūts al-'Ilmiyyah wa al-Iftā 'or the Fatwa Committee Saudi Arabia. Prioritizing texts understanding through a psychological, social context, and other perspective makes this model different from other hermeneutics. Negotiative Hermeneutics more focuses on the negotiation process for sustainable in the three pillars of hermeneutics: author, text, and reader. This iterative process on linguistic, cultural, etc. This study analyzed the weaknesses of the Negotiative Hermeneutics negotiation movement based on the misogyny fatwa case of the Saudi Arabian Fatwa Committee using the critical discourse analysis method. The results indicated that the text is ontologically sacred and authoritative; authorship of the Qur'an and the Prophet Sunnah stopped at the first author. The epistemological viewed meaning is obtained from endless negotiations among the three pillars of hermeneutics. The weakness is Khaled's disregard for the fact that the ulama's fatwa depends on royal authority. Last, the significance of this paper, especially regarding the shortcomings in Khaled's theory, is to present evidence that a fatwa produced by the ulama's ijtihad is not autonomous at all, even from the ulama itself, because it is also the result of a bargaining chip between ulama and the royal authority. 
Kata Kunci

Hermeneutika Negosiatif, Khaled Abou El Fadl, ontologi, epistemologi

\section{Abstrak}

Artikel ini menjelaskan model baru hermeneutika yang digagas oleh Khaled Abou El Fadl, yaitu Hermeneutika Negosiatif. Hermeneutika Negosiatif ini digunakan Khaled untuk mengkritik fatwa-fatwa bias gender dan misogini yang dikeluarkan oleh Al-Lajnah ad-Dā imah li alBuhūts al-'Ilmiyyah wa al-Iftā’ atau Komite Fatwa Arab Saudi. Berbeda dengan corak hermeneutika lainnya yang lebih memprioritaskan pemahaman teks atau menemukan makna teks, dengan melalui berbagai pintu masuk; psikologi, konteks sosial, dan lainnya, Hermeneutika Negosiatif lebih mengusung proses negosiasi yang berlangsung secara terus menerus antara tiga pilar hermeneutika: pengarang, teks, dan pembaca. Negosiasi makna ini berhenti sementara di halte-halte linguistik, budaya, dan lainnya; dan kemudian negosiasi tersebut berlangsung kembali. Melalui pendekatan filosofis, tulisan ini bermaksud memetakan aspek ontologis dan epistemologis Hermeneutika Negosiatif. Selain itu, dengan menggunakan metode analisis wacana kritis, tulisan ini juga akan menunjukkan kelemahan gerak negosiasi Hermeneutika Negosiatif, yang didasarkan pada kasus fatwa misogini dari Komite Fatwa Arab Saudi. Hasil kajian menunjukkan bahwa secara ontologis, Teks bersifat sakral dan otoritatif; dan kepengarangan al-Qur'an dan sunnah Rasul berhenti pada pengarang pertama. Adapun secara epistemologis, Hermeneutika Negosiatif berpandangan bahwa makna didapat dari negosiasi yang tiada henti antara tiga pilar hermeneutika, yakni pengarang, teks, dan pembaca. Kemudian kelemahan yang ditemukan dalam Hermeneutika Negosiatif adalah pengabaian Khaled terhadap fakta dependensi fatwa ulama terhadap otoritas kerajaan. Signifikansi tulisan ini, terutama mengenai kelemahan teori Khaled adalah menampilkan bukti bahwa suatu fatwa yang dihasilkan oleh ijtihad ulama sama sekali tidak otonom, bahkan dari ulama itu sendiri, sebab pada dasarnya ia juga hasil produksi tawar-menawar antara ulama dengan otoritas kerajaan atau pemerintahan

\section{Introduction}

The name Khaled Abou El Fadl - after this referred to as Khaled - has appeared in Islamic law discourse for the last two decades. He is considered a renewal in Islamic studies mostly related to understanding the text. Bernard Haykel referred to it as "one of the most accomplished liberal muslim legal scholars of our time."1

'Bernard Haykel, "Popular Support First," in Islam and the Challenge of Democracy, by Khaled Abou El Fadl (Princeton: Princeton University, 2004), 78.
The novelty brought by Khaled is Negotiative Hermeneutics that is a new understanding model in hermeneutics field to find the meaning of the text and to reveal the interests of the author and the reader behind the text. ${ }^{2}$

Initially, Negotiative Hermeneutics was used by Khaled to dismantle the gender-biased fatwas issued by Al-Lajnah ad-Dā'imah li al-Buhūts al-'Ilmiyyah wa al-Iftā' (General Committee for

${ }^{2}$ Edi Susanto, Studi Hermeneutika: Kajian Pengantar (Jakarta: Kencana, 2016), 105. 
Scientific Research and Fatwas) of Saudi Arabia. It was used later in Islamic studies widely. The characteristic of Khaled's research used Saudi Arabian scholars' fatwas as material objects with a textual character. The critical point is that the fatwas get ratification and support from the government as the official law of the Kingdom of Saudi Arabia.

The term of Negotiative Hermeneutics ${ }^{3}$ is not directly from Khaled, but rather the reader's identification of Khaled's views on the iterative negotiation process on three hermeneutic elements to find the meaning of the text. Therefore, there is no meaning to dominate hermeneutic aspects. The iterative negotiation process is blocked authoritarianism rate of the readers in understanding the text.

Furthermore, many studies developed Khaled's thoughts such as Saifudin Qudsi ${ }^{4}$ about "Khaled Abou El Fadl's perspective in blocking religious interpretation authoritarianism through negotiative hermeneutics." Qudsi explained Khaled's biography and hermeneutical features coherently. This article only described Khaled's life journey and intellectuality. However, it was not the new idea, just a review of Khaled's book entitled Speaking in God's Name: Islamic Law, Authority and Women.

The similar method was done by Atika, Muhammad Abdul Latif, and Ahmad Syafi'i in the article “Interpretation of the Women's Verses: Criticism of Gender-Biased Religious Fatwas (Study of Hermeneutic Thought Khaled M. Abou E1 Fadl)." This article discussed the examples of misogyny fatwas issued by the Fatwa Committee

\footnotetext{
${ }^{3}$ Not all Khaled's readers agree with this naming. Some have named Khaled's method with the term Authoritative Hermeneutics. See Nasrullah, "Hermeneutika Otoritatif Khaled M. Abou El Fadl: Metode Kritik atas Penafsiran Otoritarianisme dalam Pemikiran Islam," Jurnal Hunafa 5, no. 2 (2008): 137-50. However, the author personally prefers Negotiative Hermeneutics because the negotiation process is the pulse of Khaled's method in his study.

${ }^{4}$ Saifudin Qudsi, "Perspektif Khaled Abou El Fadl dalam Membendung Otoritarianisme Tafsir Keagamaan melalui Hermeneutika Negosiatif," Religio: Jurnal Studi Agama-agama 3, no. 1 (March 2013): 81-106.
}

of Saudi Arabia, which Khaled later commented on "Faith-based assumptions and determinations demeaning to women."

A new perspective on Negotiative Hermeneutics appears in Ihab Habudin work: ${ }^{5}$ "The Construction of Khaled M. Abou ElFadl's Islamic Feminism Ideas: Its Relevance to the Position of Women in the Family." He systematized Khaled's negotiative hermeneutic epistemology. He tried to contextualize Khaled's method in family legislation.

Based on the analysis of several journals, it appears that Khaled's Negotiative Hermeneutics has not received fair criticism, and researchers only repeated information. It becomes a new perspective to present the systematization of ontology and epistemology of Negotiative Hermeneutics. This criticism is essential because the context of the material object criticized by Khaled is approximately appropriate with Indonesia religious context. Saudi Arabia has a Fatwa Committee. Indonesia has Indonesian Ulema Council and other fatwa institutions affiliated with Islamic organizations, such as the Tarjih and Tajdid Council at Muhammadiyah, and Bahtsul Masail at Nahdatul Ulama.

Based on the analysis, it was found Khaled's track record on authoritative and authoritarian acts of religion theme in "And God Knows the Soldiers: before publishing "Speaking in God's Name." Speaking in God's Name was published 1997 has the same starting point based on the interpretation of Q.S. al-Muddatstsir: 31, .. And none knows the soldiers of your Lord except Him". According to Khaled, this verse describes authoritarianism in religion. The writing systematics began with text authorship problem and ended with reflection.

\footnotetext{
${ }^{5}$ Ihab Habudin, "Konstruksi Gagasan Feminisme Islam Khaled M. Abou El-Fadl: Relevansinya dengan Posisi Perempuan dalam Keluarga," Jurnal Al-Ahwāl 5, no. 2 (2012).

${ }^{6}$ Khaled Abou El Fadl, And God Knows The Soldiers: The Authoritative and Authoritarian in Islamic Discourse (Maryland: University Press of America, 1997).
} 
The difference is the depth of discussion and reflection scope. The latter book is more detailed in explaining authoritarianism issue in Islam. Khaled also gave signs so that an interpreter or Fakih would not be trapped in authoritarianism. Another difference is Khaled's reflection space. Khaled's first book seemed wandering because the reflection object was past vows. It can be concluded, Khaled makes comparisons on madzhab law. It makes different from what he did in the second book. He took the modern fatwas of the Saudi Arabian clerics as his term.

Furthermore, this paper attempts to conduct a systematic and critical reading of Khaled's Negotiative Hermeneutics. It reviews (a) overview of Negotiative Hermeneutics, (b) ontological aspects of Negotiative Hermeneutics, (c) epistemological elements of Negotiative Hermeneutics, (d) critical responses, and (e) conclusions.

\section{Hermeneutika Negosiatif ala Khaled}

As a religion emerged in the past, Islam and other samawiyah religions encountered a similar problem to implement teachings in the past for a different present context. The holy books become worn and out of date if it was only concerned on an issue where and when the book begins. However, the text serves primary reference for religious communities, some of which contain events and norms for society at that time. The main problem contextualized teachings shrouded in socio-historical to current conditions.

According to Khaerur Rizqi in his paper entitled "The interpretation from time to time: epistemological problem dilemma," there are at least three problems that must be resolved by religious believers, so that their guide to their life is not obsolete. First, all scriptures have a relatively short historical range between the time they were created and the time they were spread.

${ }^{7}$ Khaerur Rizqi, "Tafsir dari Masa ke Masa: Dilema Problem Epistemologis" (Universitas Islam Negeri Sunan Kalijaga, 2014), 1-3.
In this case, the authenticity and validity of the book need to be questioned. Indeed, the Bible and several other heavenly books were not recognized for authenticity because along the way; there have been many fixations and reductions. ${ }^{8}$ However, some Muslim intellectuals such as Aksin Wijaya and Nasr Hamid Abu Zaid argued that All-Qur' an has also been reduced, even though the two of them do not agree on the consolidated case.

In his book entitled "Suing the Authenticity of God's Revelation: Criticism of the Reason of Gender Interpretation," Aksin Wijaya says that the "reduction" of God's message occurs when the process of transmitting God's parole to Arabicspeaking people. As a "supernatural" languagethe term is called verbum dei (kalām Allāh) bi lāsaut wa lāharf-, transmission by Muhammad SAW to his scientific community, there will be a reduction. According to Aksin, what is meant by the awakening of al-Qur'an is when the kalām is at Lauh Mahfuz, and when it is transmitted to Muhammad SAW, who incidentally has a strong lāhüt element. So, al-Qur'an that is in the hands of the people today is a reduced Qur'an. ${ }^{9}$

If traced back to history, Aksin Wijaya's opinion refers to the thought of Abu Muhammad 'Abd al-Lāh ibn Sa'īd ibn Kullāb al- Qatțân al-Basrī, or better known as Ibn Kullāb (d. $240 \mathrm{H}$ ). He is one of the critical thinkers of the Muktazilah creeds. According to him, the word of Allah has only one meaning; it cannot be divided into autonomous linguistic elements; there is no amr, nor nahy. Such kalām is called kalām nafsiy. According to Ibn Kullāb, Allah's taklim on Prophet Musa in Q.S. 4:164, is not the process of speaking and speaking between humans in general, but the creation of knowledge or understanding (khalq al-idrāk) in Musa AS. ${ }^{10}$

${ }^{8}$ See Richard Elliot Friedman, Who Wrote The Bible? (New York: Harper Collins Publishers, 1997).

${ }^{9}$ Aksin Wijaya, Menggugat Otentisitas Wahyu Tuhan: Kritik atas Nalar Tafsir Gender (Yogyakarta: Magnum Pustaka Utama, 2011), 69-71.

${ }^{10}$ Muhammad ibn 'Abd ar-Rahmān Al-Khamīs, Hiwār ma' Asy'arī wa Yalīh al-Māturīdiyyah Rabībah al-Kullābiyyah 
Furthermore, there are similar thoughts from all over the world. Nasr Hamid Abu Zayd in his book Al-Imām asy-Syāfi'iy wa Ta'sīs alAidiyulüjiyyah al-Wasatiyyah stated that during his journey, al-Qur'an experienced a reduction when the Caliph Usman - with the consent of a friend - "streamlined" the qirā 'ah al-Qur' an was originally seven qirā 'àt becomes one qirā'ah that is qirā 'ah Quraish. ${ }^{11}$ John Wansbrough is an orientalist from the West who doubts the authenticity of al-Qur' an and suspects the active role of early Muslim generation in compiling the final editorial of al-Qur'an. He said, in his book Qur'anic Studies: Sources, Methods of Scriptural Interpretation, Muslims made additions to anticipate the "entry" of the Jewish tradition in al-Qur'an. ${ }^{12}$

The second problem is that the language used in the scriptures is the same as the language used by the local population. In this case, there are two consequences. First, to pronounce verbum dei with human language means that God's language will deal with the weaknesses of human language such as vagueness, inexplicitness, ambiguity, context-dependence and misleadingness. ${ }^{13}$ That is why, in some cases, the holy book (as it were) "gives" information that is "ambivalent" to everyone. ${ }^{14}$ The second consequence is through local language situation. To understand al-Qur'an, the process of translation and interpretation is a must. Although it refers to original language rule, reduction and fixation are certain things.

The third problem is the historical condition when the scriptures greet humans. In his book Anthropology of the Qur'an: A Dialectical Model

(Riyadh: Maktabah al-Malik Fahd al-Wataniyyah, 2005), 119.

${ }^{11}$ Nasr Hamid Abu Zayd, Al-Imām asy-Syāfi'iy wa Ta 'sīs alAidiyulūjiyyah al-Wasatíyyah (Beirut: Ad-Dār al-Baid̄ā', 2007), 95.

${ }^{12}$ See John Wansbrough, Qur'anic Studies: Sources and Methods of Scriptural Interpretation (New York: Promotheus Book, 2004).

${ }^{13}$ Kaelan, Filsafat Bahasa: Masalah dan Perkembangannya (Yogyakarta: Paradigma, 2002), 8.

${ }^{14}$ Sumanto al-Qurthuby, "Membongkar Teks Ambigu," in Ijtihad Islam Liberal: Upaya Merumuskan Keberagamaan yang Dinamis (Jakarta: Jaringan Islam Liberal, 2005), 15. of Revelation and Culture, Ali Sodiqin explains that the holy book does not emerge from space. There is an event that "causes" the descent of an indication from God. For instance, the verse that responds to the Prophet's "negligence" in answering unbelievers' questions about three things: Zulqarnain (Q.S. 18: 83), Ya'juj Ma'juj (Q.S. 18: 94) and the spirit (Q.S. 17: 85). Another case is about the descent of Allah's permission to fight against the unbelievers (Surah 22: 39). All of them have the cause of verse revelation - it is called asbāb an-nuzūl. Thus, denying the social and cultural context in which the scriptures were revealed is ignoring historicity and reality. ${ }^{15}$

It can be concluded that problems regarding al-Qur'an are only focused on understanding. However, the reader's interest in understanding the text must be considered as one crucial issue that has been neglected. ${ }^{16}$ It becomes essential for two reasons: first, there is the possibility of infiltration of the reader's interest in the text. Second, the reader, with his quasi-licensedivinity, has the potential to become an extreme text interpreter, inconsiderate of the text, other readers, and audience. The void in discussing the reader's authority over the text is Khaled's study material. Khaled's theory became known as Negotiative Hermeneutics.

In general, Khaled's hermeneutics is not (only) characterized by understanding the text, or finding the text meaning, but it goes beyond that. Negotiative Hermeneutics aims to dismantle the interests that readers have inserted into the text

\footnotetext{
${ }^{15}$ Ali Sodiqin, Antropologi Al-Qur'an: Model Dialektika Wahyu dan Budaya (Yogyakarta: Ar-Ruzz Media, 2012), 12.

${ }^{16}$ Actually Nasr Hamid Abu Zayd has also discussed the relationship between text (and its interpretation) and power. It's just that he moves in the space of structural criticism, namely criticism of educational institutions that restrain him from reading the Koran through the hermeneutic method. Nasr Hamid did not try to analyze more deeply the causes and impacts of the authoritarian reading. This incident occurred when he was conducting a promotion exam for the position of professor of Arabic Language and Literature at Cairo University, Egypt, through his paper entitled Al-Imām asy-Syāfi'iy wa Ta`sīs al-Aidiyulūjiyyah al-Wasatiyyah, translated by Khairon Nahdhiyyin, Imam Syafi'i: Moderatisme, Eklektisisme, Arabisme (Yogyakarta: LKiS, 2007), 21.
} 
and offer solutions to control such abuse. It goes through a negotiation process between the author, text and reader, by making the text an autonomous and open focal point. The autonomy is relative autonomy such as the autonomy from the author_ even more the author is Allah, liberated from the initial meaning, and autonomous from the initial audience. However, the independence of the text from the author does not make it closed from the original message initiated by the author. The author's note is still and will continue to be stored in the text so that the message can still be traced through endless negotiations between the three elements of hermeneutics. ${ }^{17}$ The openness of the text is a text that accepts interpretation from various approaches. The transparency of text needs to be emphasized so that there is no assumption the text is irrelevant as a way of Muslims life. ${ }^{18}$

Khaled's intended readers' interests can be found through tracing paradigms and ideologies as the basis for the reader's thinking and the foundation of a religious institution, in which the reader becomes an inseparable part of it. Besides, the interests of readers can also be traced through the political and social forces that influence the way readers think. ${ }^{19}$ One example that is quite interesting to mention is the fatwa of Al-Azhar Imam, Sheikh Ahmad Tayyeb. When the Arab Spring (الربيـع العربـي) hit Egypt, the scholars intended to maintain the status quo by issuing fatwas prohibiting demonstrations and protests, and obeying the waliyy al-amr held by Hosni Mubarak. It's just that society has long been disgusted by the corrupt Egyptian government system. Therefore, even though it was Sheikh Al-Azhar who issued the fatwa, the revolution still broke out. Finally, Hosni Mubarak and his

\footnotetext{
${ }^{17}$ Aksin Wijaya, Teori Interpretasi Ibnu Rusyd: Kritik IdeologisHermeneutis (Yogyakarta: LKiS, 2009), 37-42.

${ }^{18}$ Khaled Abou El Fadl, Speaking in God's Name: Islamic Law, Authority and Women (London: Oneworld Publications, 2001), 257-58.

${ }^{19}$ Ibid., 44
}

cronies left the palace..$^{20}$

This fatwa prohibiting demonstrations turned into a mandatory fatwa demonstration when President Muhammad Mursi was commemorating the year of his reign. ${ }^{21}$ The fatwa returns to its original state. It is a ban on demonstrating to the country's legitimate leaders when Abdul Fattah as-Sisi is leading Egypt. Support for as-Sisi came from Shaykh Ahmad Tayyeb and Dār al-Iftā fatwa institute. In welcoming the three years of the January 25 Revolution, this institution issued a fatwa on the prohibition of demonstrations, because it would destroy the order and disturb the public. The overthrow of Muhammad Mursi and the perpetuation of the power of as-Sisi utilizing a fatwa changes halal-haram by Sheikh Tayyeb. It was nothing but a form of ideological influence in reading religious texts: Sheikh Tayyeb represents the paradigm of al-Azhar as a religious organization that is against al-Ikhwān al-Muslimūn represented by Muhammad Mursi. ${ }^{22}$

\section{Negotiative Hermeneutic Ontology}

According to Khaled - and this is the basis of his negotiative hermeneutics - the text is sacred

\footnotetext{
${ }^{20}$ Irza A. Syaddad, "Fikih Revolusi: Legitimasi Gulingkan Rezim Tirani," Islam Bergerak (blog), accessed July 3, 2020, https://islambergerak.com/2016/02/fikih-revolusi-legitimasigulingkan-rezim-tirani/. When connected with Negotiative Hermeneutics, the review of ar-Raisūnı̄'s book is an attempt to delegitimize the author's intention to al-Ikhwān al-Muslimūn which was repressed by the Hosni Mubarak regime. He wrote a book that included religious propositions. The author, who is also a reader of ar-Raisūnî's work, places the text as an autonomous entity from the author's original meaning. The difference is that the writer does not negotiate meaning, but the production of meaning is controlled by the writer (the reader of the text) himself. Therefore, it is no exaggeration to focus on the support for the revolution against the corrupt government, regardless of its affiliation. See Ahmad ar-Raisūn̄, Fiqh ats-Tsaurah: Murāja' āt fì al-Fiqh al-Islāmī (Kairo: Dār al-Kalimah, 2013).

${ }^{21} R a{ }^{` a}$ Syaikh al-Azhar Yajūz at-Tazāhur wa al-Khurūj 'alā al-Hākim Muhammad Mursī, accessed November 6, 2020, https://www.youtube.com/watch? $\mathrm{v}=$ FrXldftgPic\&ab channel=IslamicEgyptNews.

${ }^{22}$ Intrigued conflict between al-Azhar as an educational and religious institution, and al-Ikhwān al-Muslimūn when their revolution succeeded in overthrowing a leader who was fully supported by his rivals, Hosni Mubarak, See Rachel M. Scott, "What Might the Muslim Brotherhood Do with al-Azhar? Religious Authority in Egypt," Die Welt des Islams 52, no. 2 (2012): 131-65.
} 
and authoritative. The text (with a large ' $\mathrm{T}$ ') is al-Qur'an. He believes that the authorship of alQur'an is not like the production of other profane texts. The point is that the authorship of al-Qur'an stops with Allah, not to the Jibril Angel, who conveyed it to the Prophet Muhammad. It is nor to the Prophet Muhammad, who passed the text to his people. It is not also to the collectors and publisher.

Khaled gave an example of the comparison between the authorship of al-Qur'an and others, to how the production of meanings involves text. For Christians, the number ' 666 ' means the license to mortgage one's soul to Satan. As for the Muslims in Khaled's circle, it does not mean anything. It became meaningful when Khaled explained to his neighbours that with this sign, Khaled had surrendered his soul to Satan. In this case, where Khaled's son scratched the number ' 666 ' on his father's forehead, Khaled's son was the first author, while Khaled was the second author.

Based on this example, a text can have many authors, namely:

"The historical author who created the text; production author who processes and prints text; revision author who edited, modified and reproduced the text; and author of interpretation who accepts and creates meanings from the symbols that make up the text." 23

It is different from al-Qur' an (and the Sunnah of the Prophet) whose authorship status stops at the first author: the author of al-Qur'an is Allah SWT, and the author of the Sunnah is Rasul SAW. The absence of further authors of these Texts makes it vulnerable to contested claims for the correctness of interpretation as a result of authorship authoritarianism. Thus it can be concluded that authorship authoritarianism moves from the direction of the readers of the text (ordinary Muslims, Muslim scholars, religious

${ }^{23}$ Khaled Abou El Fadl, Speaking in God's Name: Islamic Law, Authority and Women, 219. institutions). They seize the position of the author from the authoritative historical author (Allah) to dominate the meaning of the text.

Furthermore, according to Amin Abdullah, authoritarianism even implements the will of the divine that still has traces in the text, and closes other meanings that are different from authoritarian authors. Thus, a reader who changes his status to a strict author closes the possibility of reading and other interpretations and considers that his task is a final act, and cannot be refuted. ${ }^{24}$

Khaled's understanding of text autonomy from the original author was different from the "death of the author" movement echoed by Roland Barthes. Barthes believes that the author no longer has any power at all over the meaning produced by the text. However, it is essential and significant as the author should be ignored when someone is going to understand the text. The process of understanding the text for Barthes also ignores the original meaning that was recorded by the author. Yet, he is one voice with Khaled in the production of substances. The death of the author does not necessarily make the reader take over the position of authorship, and then tightly closes the door of interpretation. The text meaning and interpretation must not be uniform, but rather an intersection (thought), or even a contradiction to other discourses and understandings. ${ }^{25}$

\section{The Epistemology of Negotiative Hermeneutics}

Epistemologically, Negotiative Hermeneutics is meaning obtained from endless negotiations between the three pillars of hermeneutics author, the text, and the reader. Even though it looks simple; the relationship between the three is very complicated. Before starting the process of negotiating the meaning referred to by Khaled, it discusses the complexity of determining to mean.

\footnotetext{
${ }^{24}$ Amin Abdullah, "Pendekatan Hermeneutik dalam Studi Fatwafatwa Keagamaan: Proses Negosiasi Komunitas Pencari Makna Teks, Pengarang, dan Pembaca," dalam Atas Nama Tuhan: Dari Fikih Otoriter ke Fikih Otoritatif (Jakarta: Serambi, 2004), xiii. ${ }^{25}$ Laura Seymour, Roland Barthes's The Death of the Author (London: Macat Library, 2018).
} 
In the reductionist view, there are three possibilities for determining to mean. However, these possibilities did not represent the existing hermeneutic schools. The first is the author's right to determine the meaning. For those who produced language symbols, the intention is only explained by them. Therefore, the readers should follow the senses and close the possibility for new meanings. However, the characters used as a medium for conveying meaning are often not as clear as the understanding expressed. Finally, the author's desire to always control the substance produced by the reader is futile.

Second is text. The text becomes the focal point of the meaning debate between the author and the reader. If there is a debate on the meaning, it is necessary to refer to the arrangement of language symbols used by the text. Neither the author with the subjectivity nor the reader with his understanding has any prerogative in determining to mean.

Last is the reader. In this case, the author has been considered non-existent. The subjectivity of the reader is regarded as the only way to attain knowledge. Through historical contexts, scientific background, and desires, readers are free to dissect the text to bring out the meaning they want. The result is in relativism and nihilism of essential meaning. However, language has a weakness in the form of illiteracy. It can be concluded that the meaning will be subjective.

The language objectivity is obtained from the language consensus process. At first, there was a community that used a particular language. The members communicate to form the objectification of knowledge. Subjective language symbols turn into objective after being used by their members. The objectivity of language can be widespread if other language communities also accept it.

The connection with text interpretation, if the understanding and the language community do the same thing agreeing to form a text interpretation system, then a consensus must be generated through negotiations between the interpretation community and the text. Because Khaled acknowledged the active role of the text in shaping meaning, negotiations to find the meaning of the text will continue and change the interpretation community. ${ }^{26}$

It raises the question: until when does the negotiation process take place? Are negotiations moving along the path of infinity? If so, isn't it the same as meaning relativism, which Khaled denies?

It has been mentioned, Negotiative Hermeneutics makes an autonomous text from three things, and one is liberated from the first author. At first glance, this view seems to support Derrida's Deconstruction theory. In Derrida, the work of Muhammad al-Fayyadl explained that:

"There is no longer any transcendental authority who has absolute power over the text... The text is no longer formed by the author but has its autonomy. The autonomy of the text goes hand in hand with the dynamics of the interpreter and the reader. No more authorship; there are only authors who die and commit suicide, or metamorphose into interpreters and homo readers". ${ }^{27}$

Both Khaled and Derrida attempted to delegitimize the author; even though Khaled's delegitimization was to a lesser extent. However, if Derrida does not acknowledge the existence of a final stop in interpretation - what reductionists call absolute relativism - then Khaled is the opposite. Meaning relativism promoted by Negotiative Hermeneutics has meaning stops arranged by linguistics, culture, and methodology. ${ }^{28}$ As for Derrida, "meaning" or "history" is the element of

\footnotetext{
${ }^{26}$ Khaled Abou El Fadl, Speaking in God's Name: Islamic Law, Authority and Women, 198.

${ }^{27}$ Muhammad al-Fayyadl, Derrida (Yogyakarta: LKiS, 2011), 176

${ }^{28}$ Khaled Abou El Fadl, Speaking in God's Name: Islamic Law, Authority and Women, 224 In Usūl al-Fiqh, there is a rule: "Alhukm yadūr ma'a 'illatih wujūdā wa 'adamā" (the existence of law/meaning depends on the presence and loss of the 'god'). It seems that the spirit promoted by this rule is the same as the relativism of Negotiative Hermeneutics. That a meaning exists, if 'god' or cause exists, and vice versa.
} 
the journey to the impossible. ${ }^{29}$

Although Khaled's theory requires continuous negotiation, he realizes that there is a possibility of unification and even forcing the meaning of the text on the audience. It can happen when readers feel they have more authority than others. Therefore, to get a picture of the ideal negotiation that is promoted by Negotiative Hermeneutics, based on Friedman's theory of authority, Khaled divides power into two types: coercive control and persuasive authority. ${ }^{30}$

Coercive authority is the ability to direct the behaviour of others by persuading, threatening, and even punishing others, to follow the meaning they get from reading the text. This type can make a sensible person to follow without any tendency. However, Authoritarian-coercive participation of readers is due to social status rather than personal qualities, such as soldier's obedience to his leader without any effort or desire to question orders, more because of rank, not the unique qualities of the leader.

The second type is persuasive authority. It emphasizes the qualities possessed by the reader. For instance, it could come from expertise in fiqh, or wisdom, and better knowledge. Obedience that occurs is not the same in coercive authority but based on trust. If obedience to coercive authority leaves no room for rational thought, then adherence to persuasive power gives a chance to logical argumentation. The openness of opinion and logical choice is called authoritative.

The authority powers division has not yet indicated authoritarian. It is carried out when the analyst can map and understand the interpretation style. So, Khaled offers five moral principles to measure authoritarianism indication and how to control it. The five principles are honesty, diligence, comprehensiveness, reasonableness,

${ }^{29}$ Muhammad al-Fayyadl, Derrida (Yogyakarta: LKiS, 2011), 177.

${ }^{30}$ Khaled Abou El Fadl, Speaking in God's Name: Islamic Law, Authority and Women, 50. and self-restraint. ${ }^{31}$

The first principle is honesty. It is closely related to the nature of the apostles, namely siddi $q$ and amannah. The honesty outlined by Khaled applies in the words and deeds of the readers, and in the delivery of process materials, and in reading the text. The implication in the search process for the text meaning is the reader (read: representatives of God who received the invitation to circulate the text) will describe every possibility contained in the text, even though the results are contrary to their ideology. Readers are also honest about their ability to understand the text.

Second is sincerity. If a reader has been given the authority to formulate a fatwa, he must be severe in carrying out the mandate. It can be seen in the relativism principle of ijtihad truth. If the mujtahid is right, he gets two rewards. If wrong, he gets one reward. It means with the provision of seriousness (ijtihād), right or wrong of the law issued, and mujtahids still get the reward.

The third is comprehensiveness. A text reader, or law formulator, cannot rely solely on one scientific field. Multidisciplinary and interdisciplinary principles are absolutely enforced so that the meaning or formulation of the law becomes comprehensive. Furthermore, this principle, at the same time applies an open qualification to the reader being available to other scientific "interventions" in the reading process.

The fourth is rationality. This principle is relatively abstract. What qualifications make sense? Besides, these qualifications also differ between people. Khaled then explained the rationale concept by mobilizing the ability of reason to the maximum.

The last principle is self-control. It is closely related to the first type of authority. It is limiting oneself so that the reader knows the limits of the power given. This limitation is important so that the reader does not fall into the authoritarianism

\footnotetext{
${ }^{31}$ Ibid., $116-20$.
} 
of reading and meaning.

In addition to establishing signposts for readers, Negotiative Hermeneutics also pays attention to the audience. By adopting Friedman's theory of minority, 32 and Joseph Raz's theory of belief, Khaled made two kinds of his defence of audience rights. The two prerequisites are epistemological presuppositions and exclusive reasoning. The epistemological presumption is the similarity of views between the reader of the text who is God's representative, and the audience who follows his instructions. With this prerequisite, audience participation in God's representatives is no longer based on structural positions or ranks. The second prerequisite is exclusive reasoning. It allows a person to have a choice between following that authority or not. It reinforces Negotiative Hermeneutics as a theory that is pro to freedom of thought and choice of thinking results.

Khaled gave an example of how Negotiative Hermeneutics works in addressing the fatwa against women driving. ${ }^{33}$ The fatwa was issued by Sheikh Ibn Baz and Sheikh Ibn Fauzan that was later adopted by the Saudi government as official state law. The two clerics forbid women entirely to drive, even in an emergency: her husband is blind, her parents are sick, and there is no male mahram besides them. Sheikh Ibn Baz's reason was that he was worried about the mixing of a man and a woman (ikhtilāt), and seclusion (khalwah). Sheikh Ibn Fauzan added reasons in the form of losses, and the dangers that will occur if women drive cars: breaking down in the middle of the road, and accidents. The two cases occurred, according to Sheikh Ibn Fauzan, because women have limited intellectual abilities, and tend to be emotional, so they can endanger themselves and others.

Khaled then elaborated on the fatwa and found that the principles used in the istinbāt process were Sadd adz-Dzarī'ah, and Mașālị̣

\footnotetext{
${ }^{32}$ Ibid., 51.
}

${ }^{33}$ Ibid., 383-88.
al-Mursalah. In simple terms, Sadd adz-Dzarī'ah is to prevent an act that can cause damage. For instance, if driving very fast could result in an accident, then he is prohibited. If making a hole can make people fall, it is not permitted. Despite its simplicity, this concept has many problems. In the case of fast driving, how is the law for an ambulance carrying a critical patient? Will he be banned for endangering other drivers? As another example, is digging pits for burning garbage or constructing ponds prohibited? What if there was a danger sign around the hole, is it still banned?

Khaled criticized the decision of the two clerics for three reasons: first, their fatwas tended to favour men and undermine women. Second, their fatwa is considered final, thus closing the meeting opportunity for negotiations to achieve the common good, which is why they also claim that their fatwa is under God's will. Third, fatwas cover other possibilities that can even provide greater good than unproven worry or harm, such as digging a hole to supply water for the entire city. In contrast, the ones that fall in it are usually sneakers who intend to cheat the water supply.

As for Mașālih al-Mursalah, it is similar to Sadd adz-Dzarì'ah. It is the principle of goodness used to establish a law. The two concepts are like one coin: the first side resists corruption, and the other attracts kindness. As Sadd adz-Dzarī'ah, the biases surrounding Mașālih al-Mursalah are gender, closing other possibilities that have more goodness, and eliminating opportunities for negotiation.

Khaled's Negotiative Hermeneutics took on significance. It departs from the perspective of gender equality and justice. That is to be able to carry out material tests and formal fatwas to get kindness for men and women. If Negotiative Hermeneutics is applied fatwa on women driving, then women will get the same rights and opportunities as men. To achieve the common good, negotiating questions arise in the formulation of a gender-just law: 'if women lack knowledge of automotive. It is feared that cars 
will break down on the road, why don't they get the opportunity to learn about it?', And 'why are women becoming more frequent the object of ikhtilat t and khalwah law, if men also play a role in it?

Khaled's Negotiative Hermeneutics fends off obscenity and inequality in fatwas. Because in Negotiative Hermeneutics, the fatwa is flexible. Five fatwa principles bind it, and the result is to be suitable for all during the negotiation process. Unfortunately, Khaled only stopped there. He seemed to ignore the historical and social facts of the mufti, especially Saudi Arabia mufti. This weakness will change the process of negotiating the text meaning.

\section{What's Missing (and Hidden?) In Negotiative Hermeneutics}

Negotiative Hermeneutics is the possibility of meaning authoritarianism in reading a text. According to Khaled, authoritarianism is triggered by the arrogance of readers who think that - because it has been established by Allah (the author) as caliph - he is the representative of Allah who occupies His throne as the determinant of Islamic law. Such arrogance is a threat for Muslims and non-Muslims. For Muslims, the stance of determining authoritarian fatwas narrows the space for worship and mu'amalah, especially for women. For non-Muslims, the presence of an authoritarian reader closes the opportunity for dialogue without any pretence.

Furthermore, negotiative hermeneutics provides a solution by promulgating signs, both for text readers who act as special representatives and for audiences who act as general representatives. For available representatives, five moral principles must be obeyed. As for the audience, Khaled proposed preconditions for audience obedience to the meaning of text reading by a special representative. That is an epistemological presupposition and exclusive reasoning.

Khaled's Negotiative Hermeneutics contains one crucial issue that seems to have missed (or was deliberate?) Not discussed. The problem is Kingdom of Saudi Arabia (KSA) role in formulation and enactment of laws, or in short, it is called the "political map of Saudi Arabia" even though Khaled has alluded to political power playing a role in constructing readers' interests. The position of KSA is as a centre of government is represented by King Salman. It was not the senior scholars who were gathered in the Hai'ah Kibār al-'Ulamā', nor institutions such as Dār al-Iftà'. This author's criticism departs from the history of the KSA formation until now.

It is known that the Saudi Arabia government is an absolute monarchy, with Wahhabism as an official school of the state. At the beginning of the KSA formation, the coalition between the Saud family ( $\bar{a} l$-Sa'ūd), who was the kingdom founder, and the Wahabi founder family ( $\bar{a} l a s y$-Sheikh), Sheikh Muhammad ibn 'Abd al-Wahhāb, ran harmoniously for decades. Coalitions start by chance. Sheikh Muhammad ibn 'Abd al-Wahhāb, with his strong temperament and teachings, was expelled from his homeland, Nejd (or now Riyadh) and then moved to Dir'iyyah. He met the ruler Muhammad ibn Saud. Wahhabism found its nursery in Dir'iyyah. They agreed on the distribution of power: the political domain was controlled by Muhammad ibn Sa'ūd, while religion was held by Sheikh Muhammad ibn 'Abd al-Wahhāb. ${ }^{34}$ Besides, to further strengthen the position of ruler, the Sheikh issued a fatwa on the obligation to take life and death allegiance to the leader, as a manifestation of the verse

\footnotetext{
${ }^{34}$ If we trace back history, the tradition of division and amalgamation of the two authorities has long existed. During the time of Qusay, one of the Prophet's ancestors, he served as a political and religious leader. He succeeded in leading Mecca with two authorities. Many narrations say that at first, 'Abd ad-Dār, one of his sons, succeeded in leading Makkah with two authorities. The division of power began to take place in the middle of his leadership. The cause of the distribution is not certain. Only then did the Bani 'Abd Manāf get a valuable share, as well as the economic sector. Meanwhile Bani 'Abd ad-Dār got the rest from the religious and political sectors. See Hāsyim Yahya al-Malāh, Tārīkh Makkah al-Mukarramah wa ad-Da'wah al-Islāmiyyah fìhā (Beirut: Dār al-Kutub al-'Ilmiyyah, 2011), 37-39.
} 
"obeying Allah, Rasul, and ulī al-amr" (Q.S. 4:59). The coalition continued until the time when the two invaded other areas to be united under one banner.

However, this authority division dissolved when Shaykh Muhammad ibn 'Abd al-Wahhāb died in 1792 AD Abdul Aziz, Muhammad ibn Sa'ūd's son then took over the vacant religious leadership. He declared himself the leader of both the state and religion. It was under the direction of Abdul Aziz and his son, Sa' ūd that Wahhabism began to invade other areas and spread their ideological.

In summary, the KSA's journey, which began in 1744 in the Dir'iyyah area, and expanded today, was the manifestation of a coalition between the government and Wahabi ulama. However, the union of the two essential authorities began to "waver", until Hai'ah Kibār al-'Ulamā' was formed in 1971, based on the decision of the King (amr malakiy) Faisal ibn Abdul Aziz. In the same year, a religious institution was formed which was tasked with discussing community problems regarding Islamic law, and as an advisor to the King in spiritual matters. The name of the institute is Al-Lajnah ad-Dā'imah li al-Buhūts al-'Ilmiyyah wa al-Iftā' (General Committee for Scientific Research and Fatwas). A Grand Mufti leads him. ${ }^{35}$

The institution was the goal of Khaled's criticism through his Negotiative Hermeneutics. Unfortunately, Khaled ignored the political map between the government and the clerics. He was only fixated on the misogyny fatwa issued by the institution. He avoided discussing political authoritarianism. Exclusion can be justified if the authorities consider the position of the ulama to be independent. Saudi Arabian scholars rely heavily on the government. Some scholars held important positions and were even given super luxurious facilities from the kingdom. The

\footnotetext{
${ }^{35}$ The story of the activities of the early Saudi rulers with Wahabi sheikhs can be read in full at Hamid Algar, Wahhabism: A Critical Essay (New York: Oneonta, 2002).
}

personal experience of the author, who has studied in Riyadh for approximately four years, knows more or less how the kingdom made scholars rely heavily on their help. The assistance provided by the government is modern homes and resorts, and luxury cars that are replaced every three to five years.

However, it is not true that all Saudi Arabian scholars have this attitude. After 22 years of legitimate government, religious institutions were inaugurated, a sacred institution outside the royal structure was declared. It aimed to counter a blind imitation discourse of the kingdom, and protect religious rights fairly. The institution is called Lajnah ad-Difā 'an al-Huqūq asy-Syar'iyyah (Committee for the Defense of Religious Rights). The government's response was predictable. It was not only limited in movements but also many ulama affiliated with this institution were arrested. For instance, in 1994, the royal authorities arrested Sheikh Salman al-'Audah and Sheikh Safar al-Hawali, with followers. Despite having been released in 1999, Sheikh Salman al'A was arrested again in September 2017 based on a coordinated crackdown on dissent. There were also about 30 other scholars who were imprisoned. ${ }^{36}$ As of July 2018, he remained in solitary confinement without charge or trial. The news is that the arrest was allegedly due to his refusal to support the Qatar embargo initiated by the Saudi Arabian government.

Referring to the offensive and despotic royal supremacy, it is not surprising that many scholars took refuge behind the kingdom. They are not reluctant to change the fatwas that have been issued based on the domain ordered; even it goes against idealism. For instance, the fatwa is regarding the prohibition of women driving a car. The fatwa that Khaled refers to in the book

\footnotetext{
${ }^{36}$ Redaktur, "Saudi authorities arrest 30 clerics, intellectuals and activists in "coordinated crackdown on dissent," Independent (blog), accessed July 6, 2020, https://www.independent.co.uk/ news/world/middle-east/saudi-arabia-clerics-intellectualsactivists-riyadh-free-speech-a7949161.html.
} 
of Speaking in Gods Name is a fatwa issued by Sheikh Ibn Bāz in 1990.The fatwa was revised on September 26, 2017, based on the King's decree approved by the fatwa institute. ${ }^{37}$ The book Speaking in Gods Name was indeed published in 2001, but the research was conducted in the 1990s. However, looking at the track record of Saudi Arabia, especially the relationship between ulama and umara, it would be obvious how the ulama depend on umara. The existence of the term 'shopping fatwa' proved it. ${ }^{38}$

Therefore, it is not appropriate in Khaled's analysis to place scholars who issue misogyny fatwas as text readers, or special representatives. What happened was the kingdom also participated in determining the law (the meaning of the text). Therefore, there is a superstructure or external structure, which controls the hermeneutic triangle. The negotiation should occur between the reader and the text that involve the audience (reader II) in the form of royal authority. The reasons for placing royal power as the audience and the reader are beside the royal authority accepts the meaning of the text from the ulama. In this case, the royal authority becomes the audience. It also contributes to the change of meaning itself - which in this case becomes the reader. The term "reader" means a subject which, apart from reading the text, also negotiates the meaning with two other hermeneutic pillars. If the motion of dealing the meaning of Negotiative Hermeneutics and criticism of it is shown in the scheme, it will be as follows:

\footnotetext{
${ }^{37}$ Salmān ibn 'Abd al-'Azīz Āl Sa'ūd, “'Ā̄m/ Șudūr Amr Sām bi I’timād Taṭbīq Aḥkām Niẓām al-Murūr wa Lāiḥatuh atTanfîdziyyah bimā fīhā Ișdār Rukhaṣ al-Qiyādah 'alā adzDzukūr wa al-Ināts 'alā Ḥadd Sawā'," Muharram 1439, https:// www.spa.gov.sa/1671323. Due to the emergence of this fatwa, many voices have questioned the independence of the ulama, so that there is the phrase "order fatwa" (fatāwā taht at-talab).

${ }^{38}$ Read Jakob Skovgaard-Petersen, “A Typology of Fatwas," Die Welt des Islams 55, no. 3/4 (2015): 278-85. This article explains the typology of fatwas that apply in the Islamic world, especially Saudi Arabia. In Arabia, because of the large number of requests for fatwas, to the point that there is the term "fatwa confusion" ( faud $\bar{a}$ al-ifta $\bar{a}^{\prime}$ ) which refers to a conflict between one fatwa and another..
}

Scheme 1: Negotiation Meaning Movement of Negotiative Hermeneutics

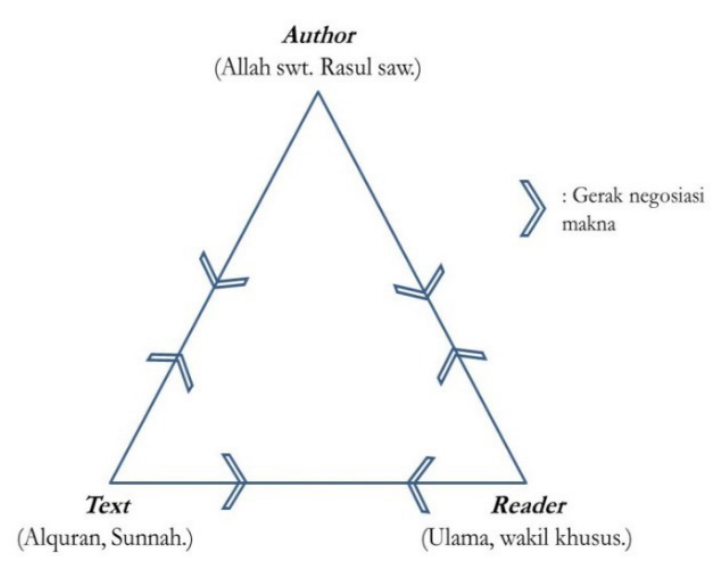

\section{Scheme 2: The Negotiation of Meaning by the Superstructure}

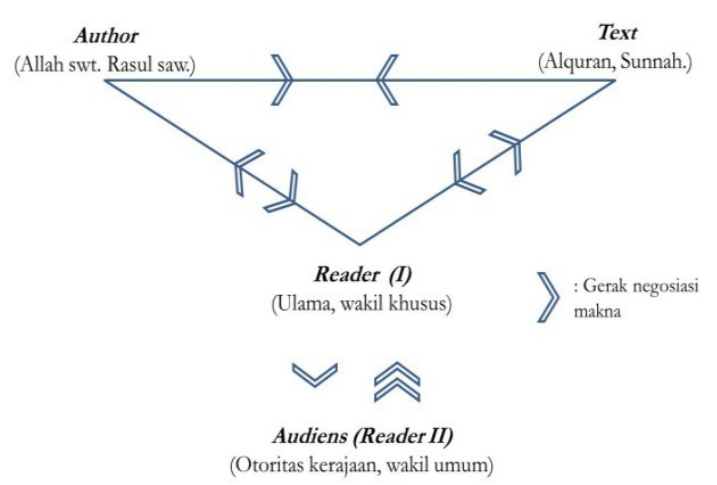

From the schematic, it can be seen that the audience also occupies a position as the second reader - the double motion of the audience shows that he is more dominant in the formulation of meaning than the reader I. The reason is that he participates in reading the text, and influences the production of meanings issued by the first reader. Even in the case of Saudi Arabia, the reading done by a reader I do not find any significance if reader II disagrees with the meaning. Therefore, the theory proposed by Khaled has the truth, if the scholars or readers of the text who are one of the pillars of hermeneutics are independent.

The case of collusion between ulama and government (umarā') is not strange. It has been commonplace, especially in countries where religion still occupies a central position in society. It also occurred during Umayyad Caliphate. It is said that when Yazid bin Abdul Malik was to be appointed caliph, 40 sheikhs were brought to him 
to ordain him as a holy man, God's messenger to lead humanity. Therefore, he was free from mistakes to fellow humans and God. He was also open to have his will and do whatever he wants for the reason of his holiness. ${ }^{39}$

Last, Khaled's criticism of fatwa issued by Saudi Arabian cleric that was later theorized as Negotiative Hermeneutics was inaccurate. Because the position of the clerics of Saudi Arabia, especially for Saudi Arabian fatwa institution, is not independent in their decisions. The royal authorities fully control it. Khaled's hermeneutics finds relevance if it is used as a tool to dissect Indonesian clerics who are still sincere in serving the ummah - regardless of whether there will be ideologies and paradigms that unconsciously infiltrate fatwas.

\section{Conclusion}

The Negotiative Hermeneutics initiated by Khaled is a new model in Islamic studies by promoting a non-stop negotiation process to get meaning. Negotiations take place between the three pillars of hermeneutics - author, text, and reader. Negotiation aims to avoid dominating one of the cornerstones of the meaning of the text.

Negotiative Hermeneutics, ontologically, is the sacredity of the authoritative text. It is different from other hermeneutics which places the text as a profane object. The sacredness and autonomy of the text do not hinder the reading and interpretation from producing the right meaning. In fact, the duality of text autonomy (open-closed) create similar sense with the original author's and to be open to various interpretations.

The weakness of Khaled's theory is the neglect of the text reader as an object of study. It does not appear to be independent and controlled by royal authorities in the formulation of fatwas. Although Khaled has made political power has a significant influence on the formation of meaning, in theory, he completely ignores it.

\footnotetext{
${ }^{39}$ Jalāl ad-Dīn as-Suyūtī, Tārīkh al-Khulafā ' (Beirut: Dār alHazm, 2003), 196.
}

\section{References}

Abdullah, Amin. "Pendekatan Hermeneutik dalam Studi Fatwa-fatwa Keagamaan: Proses Negosiasi Komunitas Pencari Makna Teks, Pengarang, dan Pembaca." in Atas Nama Tuhan: Dari Fikih Otoriter ke Fikih Otoritatif. Jakarta: Serambi, 2004. Āl-Sa'ūd, Salmān ibn 'Abd al-'Azīz. “'Ām/S Sudūr Amr Sām bi I'timād Taṭ̂īq Aḥkām Niẓām al-Murūr wa Lāiḥatuh at-Tanfīdziyyah bimā fīhā Ișdār Rukhaș al-Qiyādah 'alā adz-Dzukūr wa al-Ināts 'alā Ḥadd Sawā', ,' Muharram 1439. https://www.spa.gov. sa/1671323.

Al-Fayyadl, Muhammad. Derrida. Yogyakarta: LKiS, 2011.

Algar, Hamid. Wahhabism: A Critical Essay. New York: Oneonta, 2002.

Al-Khamīs, Muhammad ibn 'Abd ar-Rahmān. Hiwār ma' Asy'arī wa Yalīh alMāturīdiyyah Rabībah al-Kullābiyyah. Riyadh: Maktabah al-Malik Fahd alWataniyyah, 2005.

Ar-Raisūn̄̄, Ahmad. Fiqh ats-Tsaurah: Murāja 'āt fì al-Fiqh al-Islāmī. Kairo: Dār alKalimah, 2013.

Atika, Muhammad Abdul Latif, dan Ahmad Syafi'i. "Tafsir Ayat-ayat Perempuan: Kritik atas Fatwa Keagamaan Bias Gender (Studi Pemikiran Hermeneutika Khaled M. Abou El Fadl)." Equalita: Jurnal Studi Gender dan Anak 1, no. 1 (2019): 51-66. El Fadl, Khaled Abou. And God Knows The Soldiers: The Authoritative and Authoritarian in Islamic Discourses. Maryland: University Press of America, 1997.

. Speaking in God's Name: Islamic Law, Authority and Women. London: Oneworld Publications, 2001.

Friedman, Richard Elliot. Who Wrote The Bible? New York: HarperCollins Publishers, 1997. Habudin, Ihab. "Konstruksi Gagasan Feminisme Islam Khaled M. Abou El-Fadl: 
Relevansinya dengan Posisi Perempuan dalam Keluarga." Jurnal Al-Ahwāl 5, no. 2 (2012).

Haykel, Bernard. "Popular Support First.” Dalam Islam and the Challenge of Democracy, by Khaled Abou El Fadl. Princeton: Princeton University, 2004.

Kaelan. Filsafat Bahasa: Masalah dan Perkembangannya. Yogyakarta: Paradigma, 2002.

Malāh, Hāsyim Yahya al-. Tārīkh Makkah al-Mukarramah wa ad-Da'wah alIslāmiyyah fìhā. Beirut: Dār al-Kutub al-'Ilmiyyah, 2011.

Nahdhiyyin, Khairon, trans. oleh. Imam Syafi' $i$ : Moderatisme, Eklektisisme, Arabisme. Yogyakarta: LKiS, 2007.

Nasrullah. "Hermeneutika Otoritatif Khaled M. Abou El Fadl: Metode Kritik atas Penafsiran Otoritarianisme dalam Pemikiran Islam." Jurnal Hunafa 5, no. 2 (2008): 137-50.

Qudsi, Saifudin. "Perspektif Khaled Abou El Fadl dalam Membendung Otoritarianisme Tafsir Keagamaan melalui Hermeneutika Negosiatif." Religio: Jurnal Studi Agamaagama 3, no. 1 (2013): 81-106.

Qurthuby, Sumanto al-. "Membongkar Teks Ambigu.”Dalam Ijtihad Islam Liberal: Upaya Merumuskan Keberagamaan yang Dinamis. Jakarta: Jaringan Islam Liberal, 2005.

Ra `à Syaikh al-Azhar. Yajūz at-Tazāhur wa alKhurūj 'alā al-Hākim Muhammad Mursī. Accessed November 6, 2020. https://www. youtube.com/watch? $\mathrm{v}=$ FrXldftgPic\&ab_ channel=IslamicEgyptNews.

Redaktur. "Saudi authorities arrest 30 clerics, intellectuals and activists in 'coordinated crackdown on dissent." Independent (blog). Accessed December 15, 2019. https://www.independent.co.uk/news/ world/middle-east/saudi-arabia-clericsintellectuals-activists-riyadh-freespeech-a7949161.html.

Rizqi, Khaerur. “Tafsir dari Masa ke Masa: Dilema
Problem Epistemologis.” Universitas Islam Negeri Sunan Kalijaga, 2014.

Samuel, Sigal. “A Saudi Woman's 'Mixed Feelings' About Winning the Right to Drive."The Atlantic (blog). Accessed September 27, 2017. https://www.theatlantic.com/ international/archive/2017/09/saudiarabia-women-driving/541275/.

Scott, Rachel M. "What Might the Muslim Brotherhood Do with al-Azhar? Religious Authority in Egypt."Die Welt des Islams 52, no. 2 (2012): 131-65.

Seymour, Laura. Roland Barthes's The Death of the Author. London: Macat Library, 2018.

Skovgaard-Petersen, Jakob. "A Typology of Fatwas." Die Welt des Islams 55, no. 3/4 (2015): 278-85.

Sodiqin, Ali. Antropologi Al-Qur'an: Model Dialektika Wahyu dan Budaya. Yogyakarta: Ar-Ruzz Media, 2012.

Susanto, Edi. Studi Hermeneutika: Kajian Pengantar. Jakarta: Kencana, 2016.

Suyūtī, Jalāl ad-Dīn as-. Al-Itqān fì 'Ulūm alQur 'ān. Arab Saudi: Wizārah asy-Syu 'ūn al-Islāmiyyah wa al-Auqāf wa ad-Da'wah wa al-Irsyād, n.d.

- Tārīkh al-Khulafā '. Beirut: Dār al-Hazm, 2003.

Syaddad, Irza A. "Fikih Revolusi: Legitimasi Gulingkan Rezim Tirani." Islam Bergerak (blog). Accessed December 15, 2019. https://islambergerak.com/2016/02/fikihrevolusi-legitimasi-gulingkan-rezim-tirani/.

Wansbrough, John. Qur'anic Studies: Sources and Methods of Scriptural Interpretation. New York: Promotheus Book, 2004.

Wijaya, Aksin. Menggugat Otentisitas Wahyu Tuhan: Kritik atas Nalar Tafsir Gender. Yogyakarta: Magnum Pustaka Utama, 2011. - Teori Interpretasi Ibnu Rusyd: Kritik Ideologis-Hermeneutis. Yogyakarta: LKiS, 2009.

Zayd, Nasr Hamid Abu. Al-Imām asy-Syāfi'iy wa Ta sìs al-Aidiyulūjiyyah al-Wasatiyyah. 